\title{
Amar la duda en la educación odontológica
}

\author{
Loving doubt in dental education
}

\author{
Américo Durán Gutiérrez*
}

\begin{abstract}
"La duda es un estado incómodo; la certeza intelectualmente, un estado ridículo.»
\end{abstract}

\section{Miguel Ángel Santos Guerra, intelectual catedrático de la Universidad de Málaga.}

La práctica odontológica no debe considerarse una mera aplicación directa de la teoría, sino un escenario complejo, incierto y cambiante, donde se producen interacciones que vale la pena observar, relacionar, contrastar, cuestionar y reformular, ya que son espacios y procesos generadores de nuevos conocimientos. ${ }^{1} \mathrm{La}$ interacción permanente de la práctica y la teoría conforma un bucle creativo y dinámico que expande el conocimiento y transforma la realidad al transformar al propio sujeto que conoce y actúa como consecuencia de su interacción con la realidad; esto se relaciona directamente con las guías de práctica clínica, las cuales se deben considerar como un auxiliar en la atención del paciente, mas no como un cúmulo de normas que tendrán que seguirse al pie de la letra.

Las teorías declaradas, verbalizadas y en uso, así como el conocimiento en la práctica clínica médica y estomatológica de cada individuo, constituyen universos relacionados y complementarios, pero independientes y a veces discrepantes.

La vida cotidiana personal, social y profesional de un individuo en general y del profesional de la salud de modo muy particular, compone un escenario complejo, incierto, imprevisible, cargado de valores y presionado por la urgencia de las reacciones inmediatas. En este escenario, es el pensamiento práctico -las teorías en uso, no las teorías declaradas- el que gobierna las interpretaciones y acciones del profesional de la salud.

La investigación contemporánea plantea pocas dudas sobre el carácter holístico y emergente del conocimiento práctico. El pensamiento práctico parece el lugar adecuado para comprender la integración invariable pero compleja de los elementos lógicos y racionales con los emotivos y motivacionales de nuestros sistemas de interpretación y acción. Está formado por un repertorio de imágenes, mapas o artefactos, conscientes e inconscientes, que traen consigo informaciones, asociaciones lógicas, deseos y connotaciones emotivas. Los significados o representaciones que los seres humanos construyen y reconstruyen en sus interacciones poseen componentes cognitivos y componentes emocionales, conscientes o inconscientes, integrados de modo indisoluble en la unidad compleja de representación. Sin el componente emocional y valorativo no puede entenderse la naturaleza compleja del pensamiento y la conducta humana: somos seres emocionales, complementados con un toque muy fino de la racionalidad.

El aprender supone reconstruir, ${ }^{2}$ reestructurar ${ }^{3}$ y redescubrir de una manera consciente y sistemática el entramado de representaciones o significados que cada individuo ha ido construyendo a lo largo de su historia personal, a propósito de sus interacciones en los escenarios cotidianos. Aprender supone incrementar y repensar los saberes que surgen de la experiencia vivida y pensada de cada sujeto, para ampliar el horizonte de nuevas experiencias y nuevos saberes.

Se trata de involucrarse en una espiral interminable de conocimiento que evalúe la aplicación del conocimiento mismo mediante la experimentación, demostración y contextualización, ${ }^{4}$ pero alcanzando cada vez más conocimiento, mayor experiencia, y que la posibilidad de aplicarlos en un contexto real sea factible (Figura 1).

Los estudiantes construyen conocimiento interpretando, analizando, evaluando y, al mismo tiempo, interviniendo, no simplemente recitando información. La labor docente está en tener la humildad suficiente para escuchar con atención el nuevo conocimiento, guiando una correcta interpretación del aprendiz.

\footnotetext{
* Profesor adjunto de la Especialidad en Estomatología Pediátrica. Instituto Nacional de Pediatría.
}

Este artículo puede ser consultado en versión completa en http://www.medigraphic.com/facultadodontologiaunam 


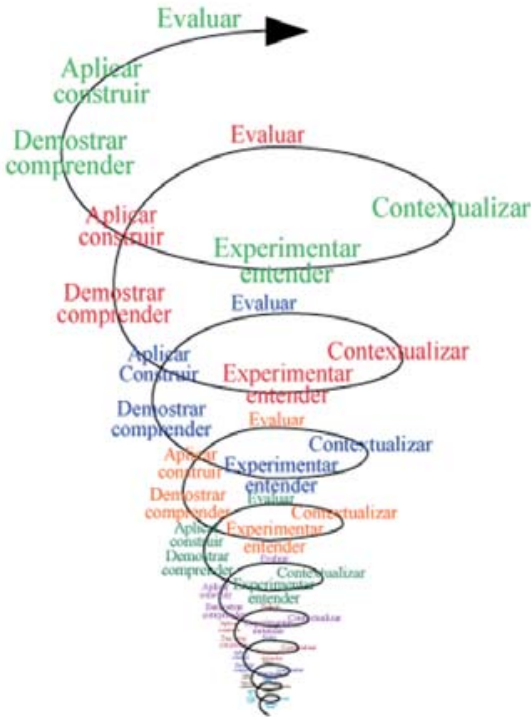

Figura 1. Espiral ascendente del conocimiento.

El conocimiento que merece la pena en la educación odontológica tiene valor de uso, para descubrir y crear nuevos horizontes o para resolver problemas y mejorar las condiciones de vida. El intercambio del conocimiento por calificaciones ha de ser, en todo caso, una mera condición secundaria.

La formación escolar o curricular del conocimiento práctico en general, y del odontológico en particular, dentro de esta perspectiva epistemológica aconseja lo siguiente:

- Partir de cuestiones abiertas y problemas reales (aprendizaje basado en problemas), prestando especial atención a las áreas de incertidumbre y controversia.

- Utilizar fuentes primarias de información. El paciente es la fuente privilegiada de información.

- Cuestionar las propias concepciones vulgares, crear nuevas propuestas e interpretaciones clínicas, experimentar en la práctica de forma responsable y utilizar nuevo conocimiento en nuevos contextos como procedimiento metodológico, didáctico, más valorado. ${ }^{6}$

- Fomentar la cooperación, dar el valor real al concepto «interdisciplinario», generando el debate, la sinergia de recursos compartidos, el contraste de pareceres y experiencias. Los estudiantes médicos han de enfrentarse a la discrepancia entre diferentes investigadores sobre cuestiones controvertidas, asumiendo la relatividad constitutiva del conoci- miento humano, y así tomar la mejor decisión posible.

- Enfatizar la concentración en un área de trabajo o foco de atención que requiera solución inmediata mediante un análisis diagnóstico de las necesidades sociales, más que abarcar colecciones enciclopédicas interminables de información -datos con pretensión de exhaustividad que al final no tienen utilidad práctica.

- Concebir el currículo más como conjunto de problemas y situaciones relevantes, disciplinares 0 interdisciplinares que retan la capacidad de comprensión y acción de los médicos aprendices, que como conjunto de fragmentos disciplinares yuxtapuestos; no basta con enseñar contenidos disciplinares descontextualizados (anatomía, fisiopatología, genética, ética, medicina interna, etcétera); se requiere definir situaciones en las cuales los odontólogos en formación puedan construir, modificar o refutar conocimientos y habilidades utilizando contenidos disciplinares. Los docentes que valoran esta forma de pensar el currículo proporcionan a los estudiantes tiempo para pensar problemas sobre lo que merece la pena trabajar y otros compañeros con los que pensar. ${ }^{5}$

El verdadero valor del maestro/tutor en el área odontológica y en todas las áreas de la salud está en saber guiar al aprendiz para obtener la mejor versión de sí mismo, mostrando interés por sus logros y aceptado los retos clínicos que esto pueda suponer. Se acabaron las lumbreras o las enciclopedias vivientes; en estos tiempos, con el cúmulo de información que se maneja en los medios, aquel profesional de la salud formador de recursos humanos que imponga sus teorías como verdaderas y únicas está condenado irremediablemente al fracaso.

\section{REFERENCIAS}

1. Gergen K. Social constructions in context. Londres: Sage; 2001.

2. Pérez-Gómez Al. La cultura escolar en la sociedad neoliberal. Madrid: Morata; 1998.

3. Pozo Jl, Scheuer N, Pérez M, Mateos M, De la Cruz M. Nuevas formas de pensar la enseñanza y el aprendizaje. Las concepciones de profesores y alumnos. Barcelona: Graó; 2006.

4. http://www.mathematike.org/pages/methodology.html

5. Daniels H, Bizar M. Teaching the best practice way: Methods that matter. Portland, ME: Stenhouse Publishers; 2005.

6. http://www.funiber.org/areas-de-conocimiento/formacion-profesorado/master-en-educacion

Dirección para correspondencia: Dr. Américo Durán Gutiérrez E-mail: dr_americo@ hotmail.com 